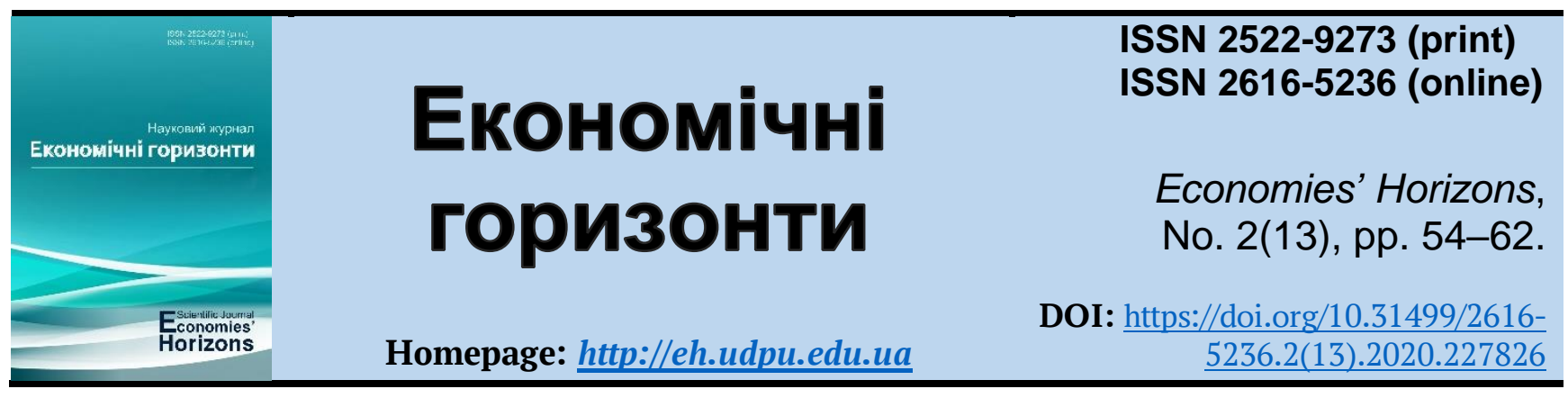

UDC 314.113+332.14]:316.334.55

\title{
Socio-demographic and socio-economic fundamentals of rural development
}

\author{
Maksym O. Skochko ${ }^{1}$ \\ Karyna V. Shapovalyuk ${ }^{2}$
}

Received: 8 May 2020

Accepted: 12 June 2020
Skochko, M. O. and Shapovalyuk, K. V. (2020), "Socio-demographic and socio-economic fundamentals of rural development”, Economies' Horizons, no. 2(13), pp. 54-62. doi: https://doi.org/10.31499/2616-5236.2(13).2020.227826

Abstract. The purpose of the study is the socio-demographic and socio-economic development of rural areas in Ukraine. Methodology. The study's methodological basis is the method of theoretical generalization, comparison, systems approach, and systems analysis. Results. The peculiarities of regulating the social development of rural areas from the demographic and economic point of view are characterized, the socio-demographic and socio-economic development of rural areas is generalized. It is established that the state of social infrastructure sets the task of successful social development of rural areas. The living climate in the rural territorial network highlights the latest research and publications of socio-demographic development of rural areas and theoretical and methodological provisions of socioeconomic development of rural areas, analysed the features of solving problems of preservation of rural areas in Ukraine. It is revealed that the solution of problems of preservation of rural territories and labour potential is necessary by creation of social, industrial, engineering interaction of urban and rural areas. Practical meaning. It consists of the generalization of socio-demographic and socio-economic development of rural areas. Based on this work, the relevance of this topic for modern society is determined. Prospects for further study. Socio-demographic and socio-economic development of rural areas depends on the effective implementation of its own competitive advantages. Further research will be devoted to the issues of socio-demographic and socio-economic development of rural areas in Ukraine.

Keywords: agriculture, rural territory, public administration, rural area, economic modernization, rural tourism, agricultural production, demographic development.

JEL Classification: H53, I3, 035, R58.

Number of references: 31; number of tables: 0; number of figures: $\mathbf{0}$; number of formulas: 0.

\footnotetext{
${ }^{1}$ Pavlo Tychyna Uman State Pedagogical University; postgraduate student at the Department of Social Pedagogy and Social Work; ORCID ID: http://orcid.org/0000-0003-2342-3834; e-mail: skochko1993@ukr.net.

${ }^{2}$ Pavlo Tychyna Uman State Pedagogical University; Lecturer at the Department of Psychology; ORCID ID: http://orcid.org/0000-0002-4657-1402; e-mail: shapovalyuk_karina@ukr.net.
} 


\title{
Соціально-демографічні та соціально-економічні засади розвитку сільської місцевості
}

\author{
Максим Олександрович Скочко \\ Карина Володимирівна Шаповалюк ${ }^{2}$
}

Стаття надіŭшла: 08.05.2020 Стаття прийнята: 12.06.2020
Skochko M. O., Shapovalyuk K. V. Socio-demographic and socio-economic fundamentals of rural development. Економічні горизонти. 2020. № 2(13). C. 54 62. DOI: $10.31499 / 2616-5236.2(13) .2020 .227826$

Анотація. Мета дослідження. Головною метою дослідження є соціально-демографічного та соціально-економічного розвитку сільської місцевості в Україні. Методологія. Методологічною основою дослідження стали методи теоретичного узагальнення, порівняння, системного підходу та системного аналізу. Результати. Охарактеризовано особливості регулювання соціального розвитку сільської місцевості з демографічної та економічної точки зору, узагальнено соціально-демографічний та соціально-економічний розвиток сільської території, встановлено, що стан соціальної інфраструктури сільської місцевості ставить перед собою завдання успішної реалізації соціального розвитку сільських територій, започаткувати повною мірою соціально-життєвого клімату в сільській територіальній мережі. Проведено аналіз теоретичних і методологічних положень соціально-економічного розвитку сільських територій, розглянуто особливості вирішення проблем збереження сільських територій в Україні. Виявлено, що вирішення проблем збереження сільських територій і трудового потенціалу можливе шляхом створення соціальної, виробничої, інженерної взаємодії міської та сільської місцевості. Практичне значення полягає в узагальнені соціально-демографічного та соціально-економічного розвитку сільської території. На основі проведеної роботи визначено актуальність даної теми для сучасного суспільства. Перспективи подальших досліджень. Соціально-демографічний та соціально-економічний розвиток сільської місцевості залежить від ефективної реалізації їі власних конкурентних переваг. Питанням соціально-демографічного та соціально-економічного розвитку сільської місцевості в Україні будуть присвячені подальші наукові дослідження.

Ключові слова: сільське господарство, сільська територія, державне управління, сільська місцевість, економічна модернізація, сільський туризм, аграрне виробництво, демографічний розвиток.

Кількість джерел: 31; кількість таблиць: 0; кількість рисунків: 0; кількість формул: 0.

\section{Introduction.}

From a demographic point of view, the history of mankind is a continuous process of population growth. It was constantly hampered by epidemics, wars, famines, but still has a permanent character. The increase in population both conditioned and required the division of labor, the separation of certain areas of activity, including mental; reunification of people into larger settlements, which later became cities; development of trade, increasing contacts between different civilizations. This led to the transfer of knowledge, new technologies - all that in the broadest sense is now called science. The development of science contributed to the development of the economy, military affairs, social relations, gradually increasing people's knowledge of themselves and improving living conditions (Hladun, 2018).

\footnotetext{
${ }^{1}$ Уманський державний педагогічний університет імені Павла Тичини; аспірант кафедри соціальної педагогіки та соціальної роботи; ідентифікатор ORCID: http://orcid.org/0000-0003-2342-3834; e-mail: skochko1993@ukr.net.

2 Уманський державний педагогічний університет імені Павла Тичини; викладач кафедри психології; ідентифікатор ORCID: http://orcid.org/0000-0002-4657-1402; e-mail: shapovalyuk_karina@ukr.net.
} 
Agriculture has traditionally been considered to be in secondary roles compared to industry. Thus, the experience of the world's leading countries was ignored, where market relations so regulated economic sectors that they were in a permanently equivalent socioeconomic situation and developed under the influence of fierce intra-industry and inter-sectoral competition.

Due to the heterogeneity of scientific and public opinion and attempts to defend a purely domestic or foreign experience, it enjoys political instability, which distracts public authorities from carrying out profound transformations. To support the development of revival processes in agriculture as well as the traditional contempt in society for the law, its meaning and role.

Soviet practice persisted for a long time, when political decisions prevailed over legal ones. It should be noted that in the late 1980 s, even with an understanding of the need for radical economic change, the availability of widespread promotion of business initiative, and its support by the general public, political decisions alone failed to advance the cause. Especially in the early 1990s, there was legal inconsistency, and the Ukrainian countryside was deliberately held hostage to the political situation. Accordingly, no legislation has been created that would perform such a cardinal function as protecting peasants and villages from arbitrary circumstances, dishonest government officials, and instability of market conditions.

Agriculture has experienced economic decline. Evidence of this was a significant reduction in its resource potential. At the same time, despite these troubles, the scale of domestic production was generally preserved. The changes proposed "from above" were made possible by the plastic and generally positive reaction of the peasantry. Such economic problems as the inefficiency of the financial and credit system, deteriorating logistics, reduced investment, price disparities, underdeveloped agricultural market have become possible largely due to the predominance in the actions of government agencies to actually fill the slogan "priority of agriculture" formalism and declarative ness (Padalka, 2016).

\section{Problem analysis.}

The current conditions require effective mechanisms to create favorable conditions for integrated rural development, highly competitive in both domestic and foreign markets, solving social problems of the village, ensuring food security, preserving the peasantry as a carrier of Ukrainian identity, culture and spirituality (Kliuchnyk, 2011).

Constant changes in economic conditions have sharply highlighted the problem of socio-economic development of rural areas in front of the regions of Ukraine (Klub, 2013).

In the context of the formation of a new paradigm of public administration with increasing levels of decentralization and intensification of local economic and social development, the relevance of systematic research of rural settlement becomes especially important. In the context of modern modernization transformations there are structural and functional changes of the systems of rural settlement formed for the previous historical period (Zaiats (ed.), 2017).

\section{Literature review.}

Issues of socio-demographic development of rural areas for a long time are widely covered in the scientific literature. Reproduction of the rural population, demographic prospects of the Ukrainian countryside, principles of demo-politics, demographic and labor potential of the Ukrainian peasantry, socio-economic development of rural areas and the revival of the Ukrainian countryside were studied by O. Bulavka (2013), V. Nelep (2014), S. Pyrozhkov (2008), P. Sabluk and K. Yakuba (2002), L. Tranchenko (2012), M. Khvesyk and Yu. Khvesyk (2013), K. Yakuba and P. Sabluk (Yakuba and Sabluk, 2011, p. 3340), K. Yakuba (Yakuba, 2011, p. 60-65) and others.

A significant contribution to the development of theoretical and methodological provisions of socio-economic development of rural areas was made by M. Butko (Butko, 2007, 
p. 36-44), O. Harkusha (Harkusha, 2014, p. 178-180), A. Klyuchnik (2011), P. Shylepnytskyi and V. Povoroznyk (2015) and others.

\section{Methods.}

To achieve the goal in the article, the research was based on methods of theoretical generalization, comparison, systems approach and systems analysis.

\section{Research objectives.}

The purpose of the article is used in the study of socio-demographic and socio-economic development of rural areas in Ukraine.

\section{Results and discussions.}

Demographic development is a process of preserving the size of the population as a result of historical progress. When this measure is drastically violated due to the decline in the quality of the population, there is a demographic crisis, during which demographic development is slowed down, there is a "demographic stagnation", which may eventually turn into a demographic catastrophe. The demographic catastrophe is guided by the transformation of the country or its individual regions into areas of demographic poverty, which is manifested in the mass outflow of population from them, in the partial or complete depopulation of territories. In Ukraine, such areas of demographic disaster are, first of all, rural areas (Steshenko, 2013, p. 5-16).

Demographic changes in rural areas directly determine the prospects for the development of the agricultural sector of the economy, and hence the provision of Ukraine with agricultural products. However, such influence is not one-sided. The course of events in the socio-economic sphere of the village, the effectiveness of agricultural policy and the effectiveness of management largely determine the content of demographic processes. Therefore, it is worrying that in the pages of well-known economic publications the current vector of state agricultural policy is openly called irresponsible and incompetent.

Agrarian policy remains not much more effective today: the agricultural sector is experiencing an acute shortage of investment and credit resources, left alone with the problem of high depreciation of fixed assets, the need for technological re-equipment of enterprises, and thus low competitiveness of domestic products, including foreign markets, where standards and requirements for the quality of not only the final product, but also raw materials and technologies of its installments - are fundamentally different. This situation requires urgent reform of relations in the agricultural sector. An important prerequisite for solving this problem is the awareness of relevance, research and implementation of ideas for demographic development of rural areas (Melnychuk, 2014, p. 131-141).

As of January 1, 2020, the number of inhabitants of Ukrainian villages compared to 2019 decreased to 12.77 million people and amounted to $30.46 \%$ of the total population of Ukraine (State Statistics Service of Ukraine, 2020).

Destructive demographic processes, lack of jobs, low wages, unsatisfactory development of the network of social facilities necessary for the proper livelihood of the rural population, threaten the preservation and reproduction of labor potential of the village, entrepreneurial initiative, prospects for many villages as such. This requires the development and implementation of a systemic state policy to address the acute socio-economic problems of the rural population (Melnychuk and Shpytalenko, 2016, p. 57-64).

Today, the development of the agricultural sector of Ukraine is hampered by a number of unresolved issues that have accumulated during the reform period, the key of which is the lack of a state program. The need for its development is due to the fact that so far there is virtually no document that would provide for a comprehensive and systematic development of the Ukrainian countryside in the future. Previous programs were based on sectoral and narrowly problematic principles, their main task was to increase production in various industries. This one-sided approach has created a situation of erroneous priorities 
and inconsistent state policy towards the village itself, the rural population and rural areas in general.

The economic situation of the rural population of Ukraine is characterized by low quality of life, high unemployment, functional type of labor use and underdeveloped production and social spheres. For 55 percent of the rural population, the only source of livelihood is farming on their own plots. Such a small amount of land ownership does not allow the population employed in the household to receive sufficient income, which leads to a high level of poverty in rural areas of Ukraine (Malik and Khvesyk, 2010, p. 3-12; Movchaniuk and Diachenko, 2018).

Throughout to the low level of local development of rural areas, small land plots of private farms, lack of financial assets, machinery, high prices for means of production (seeds, livestock, etc.), low quality infrastructure and lack of access to markets, small farms are unable to receive added value and ensure a positive cycle of investment accumulation (Pavlov, 2014).

The economic basis of rural settlements in Ukraine is gradually transformed under the influence of contradictory socio-political relations, educated geopolitical enterprises, changes in ownership, decentralization of economic management, its liberalization, as well as a significant increase and intensification of self-regulatory principles of settlement processes. The historically formed network of rural settlements in Ukraine and one of them socially developed parts of Ukrainian society the rural population as the least adaptation to socio-economic modernization - is returning under the significant influence of these transformers, which unfortunately limit their development and possibly reduce disintegration. systems in a single national settlement system.

In the conditions of aggravation of modern global political and social problems and actualization of tasks of modernization of economy of Ukraine rural resettlement should be considered as an important element of strategic potential of the state - on the one hand, and open transformational system with close internal and population and the specifics of its location in the country is an indicator of the effectiveness of modernization reforms - on the other. Rural resettlement as an integral part of a single national resettlement system, represented by different types of settlements, which are classified according to certain characteristics. Therefore, it is necessary to recognize at the state level its priority to strengthen the socio-economic potential of the country's regions by preventing and minimizing unwanted migratory losses of the economically active population due to lack of proper living and employment conditions, as well as restoring rural settlements.

Unfortunately, as a result of the longterm persistence of signs of a systemic sociopolitical and socio-economic crisis in Ukrainian realities, destructive processes caused by the reduction and fragmentation of the settlement network, depopulation of some rural settlements as a result of natural and migratory population decline, combined with low territorial accessibility of vital social services and inadequate payment for agricultural labor is becoming another, no less acute problem of survival of the country's rural population (Zaiats (ed.), 2017).

Due to mass unemployment and hopelessness, intolerable living conditions, the most active part of the peasants left the villages in search of a better life, as a result of which families break up and children grow up without proper care and upbringing. The deformation of the age structure of the rural population has sharply increased. Today for every thousand able-bodied people in the village there are about 760 pensioners and the incapacitated (Melnyk, 2007, p. 218-224).

The devastation in the agricultural sector has led to the fact that agriculture has become an unpromising field of activity for rural youth. With few exceptions, in villages it is either impossible to get a job in an agricultural enterprise, or the proposed amount of wages is unacceptable for a young and active person. The prospects of organizing or inheriting a 
farm are also disappointing: the difficult conditions for the functioning of most of these farms hinder the development of the farming system. According to sociological research, only $9 \%$ of young peasants have organized their own farm or are going to do so. Young people are not satisfied with hard and unproductive work in private farms, where it is almost impossible to organize efficient commodity production. The quality and level of education of rural youth is deteriorating, the share of those who have only basic general and primary education is increasing, and this is most noticeable among 15- to 19-year-old peasants. This is closely related to the unsatisfactory material living conditions of the majority of rural residents and the critical condition of the network of rural secondary schools (Pavlov, 2006, p. 41-48).

In Ukraine, rural tourism is an effective tool for creating new jobs and developing infrastructure. In most European countries, clusters in rural tourism are encouraged at the state level. It is no coincidence that in these countries the share of eco-travel is more than $20 \%$ of all tourist services, and the annual growth rate reaches 30\% (Neshchadym, 2011, p. 158159).

In a number of developed Western European countries, such as France, Great Britain, Holland, Ireland, Germany, and Spain, rural tourism is an integral part of the program of integrated socio-economic development of the village. In developed countries, tourist trips to villages and rural areas are already second only to sea recreation. World practice confirms that rural tourism actively contributes to solving the main socio-economic problems of the village.

In the West, this type of activity has long and successfully developed and brings a stable significant income to the rural population along with the main activity.

Today, the main areas of rural green tourism in Ukraine are the Crimea and the Carpathians. It is developing especially intensively in the Carpathian region - Ivano-Frankivsk, Transcarpathian and Lviv regions. The number of "green" estates in Chernivtsi and Volyn regions is increasing (Prodius, 2009, p. 76-79).

Rural tourism has convincingly proved that it is an important factor in solving socioeconomic problems of the village - It is the growth of employment in rural areas, development of rural infrastructure, obtaining stable and significant incomes of peasants, strengthening the budget of rural settlements. It is a multifunctional phenomenon that is actively spreading in the economic life of Ukraine and contributes to economic and social development (Neshchadym, 2011, p. 158-159).

Given the general economic crisis in Ukraine, in particular the aggravation of rural problems, the widespread and development of rural green tourism is particularly desirable here. A systematic approach to the organization of this new type of Ukrainian tourism can and should promote the development of not only domestic but also foreign tourism, as a way to expand international relations and mutually beneficial cooperation (Boiko and Boiko, 2010).

In the context of the socio-economic crisis, the real task that should be consistently implemented is to ensure a minimum level of income for rural residents. It should be emphasized that the preservation of the characteristic for modern conditions of a high share of income from personal farming in the overall structure of total income of rural households in the future is seen as negative. This indicator is evidence, on the one hand, of the naturalization and intensification of agricultural production due to its fragmentation; on the other hand, the low level of monetary income of peasants, received in the form of wages, pensions, scholarships. Although it is also necessary to recognize the significant contribution of personal farms in ensuring food security of our state, which was made in the deep economic and industrial crisis in which agricultural enterprises found themselves.

However, just expect the revival of the village with the improvement of the situation in the agricultural sector would be 
irresponsible. The state pursues an active policy in this area, along with measures aimed at improving the efficiency of production in agriculture.

Along with the development of agricultural production and bringing it to a new economic level, an important factor in rural development should be state support for the development of non-agricultural forms of entrepreneurship in rural areas. This will help increase jobs in rural areas and reduce their dependence on the success of agricultural enterprises.

The current sphere of employment of the rural population is characterized as absolutely redundant labor, as evidenced by declining employment (able-bodied population, rising unemployment, increasing the share of unskilled labor observed in rural areas.

Historically, the scope of employment in rural areas was less diverse than in the city and was characterized by a lower share of those employed in the fields of social services (health care, education, etc.), as well as in the construction and industrial processing of raw materials (Lytvyn, 2012, p. 119-122).

Rural settlements in Ukraine can be divided into main types according to their production profile, functional criteria. Thus, according to the production profile, there are three main types of settlements: agricultural, non-agricultural and mixed. The main production function of agricultural settlements is agricultural production. As a result of the process of urbanization, a large number of various nonagricultural rural settlements were formed near the cities. Such settlements are concentrated in the immediate vicinity of cities, forestry areas, near railway stations, country settlements. They have no direct connection with agriculture, but the small population of these settlements does not allow them to be classified as cities. A significant part of the number of rural settlements is occupied by villages mixed in their production functions. They are characterized by the fact that most of the inhabitants are employed in agriculture, but there are also those who work in industry, forestry, transport, services. Many mixed settlements play the role of local administrative, economic and cultural centers in the rural areas of the region, as they are the largest and most diverse in their functions among other rural settlements.

In the conditions of transformation of public relations and economic crisis for rural settlements the tendency of loss by the majority of villages of the status of agro-industrial centers and transition to the status of agrarian is characteristic (Illiash and Tkach, 2013).

In the formation of the social sphere of life of rural workers it is necessary to influence not only the factor that is at a minimum, but also its indirect factors. At the same time, one cannot ignore the predominant influence of one or another factor at the regenerative stage of rural development and the associated needs of certain needs as the individual becomes physically and spiritually. The problem of social development of the village can be successfully solved taking into account the action of all socio-economic factors in their dialectical combination and relationship, that is, with a systematic approach to the impact of a set of needs and planning activities to meet them more fully (Riabokon, 2015, p. 57-63).

\section{Conclusions.}

Consequently, the state of the social infrastructure of rural areas sets itself the task of successful implementation of social development of rural areas, to fully start the social and living climate in the rural territorial network.

The connection with certain objective and subjective reasons in rural areas gives rise to a social decline, which is highlighted, in itself, inconsistency with the expected results in the implementation of state agricultural policy, lack of material support, low level of control over the implementation of regulations. issues of social development of rural areas.

Socio-demographic and socio-economic development of rural areas depends on the effective implementation of its own competitive advantages. Solving the problems of preservation of rural areas and labor potential is necessary by creating social, industrial, engineering interaction of urban and rural areas. 


\section{References}

Boiko, Ye. O. and Boiko, O. S. (2010), “The role of green tourism in the countryside”, Ekonomika. Upravlinnia. Innovatsii, [Online], no. 1, available at: http://nbuv.gov.ua/UJRN/eui 201013 (Accessed 4 May 2020)

Bulavka, O. H. (2013), "Continuous certification of villages in Ukraine is the basis for the development of rural areas”, Ekonomika APK, no. 2, pp. 77-80.

Butko, M. P. (2007), "State regulation as a tool to increase the capacity of regions", Ekonomika Ukrainy, no. 6, pp. 36-44.

Harkusha, O. M. (2014), "State regulation of rural development”, Hlobalni ta natsionalni problemy ekonomiky, no. 2 , pp. $178-180$.

Hladun, O. M. (2018), Narysy z demohrafichnoi istorii Ukrainy XX stolittia [Essays on the demographic history of Ukraine in the twentieth century], NAN Ukrainy, Instytut demohrafii ta sotsialnyh doslidzhen im. M. V. Ptukhy, Kyiv, Ukraine, $224 \mathrm{p}$.

Illiash, I. D. and Tkach, D. V. (2013), Sotsialno-ekonomichnyi rozvytok poselen ahropromyslovoho rehionu $v$ umovakh transformatsii suspilstva [Socio-economic development of settlements of the agro-industrial region in the conditions of society transformation], Aston, Ternopil, Ukraine, $204 \mathrm{p}$.

Khvesyk, M. A. and Khvesyk, Yu. M. (2013), "Sustainable development of the territory as a basis for the development strategy of the agricultural sector", Ekonomika APK, no. 1, pp. 66-76.

Kliuchnyk, A. V. (2011), Formuvannia ta rozvytok ekonomichnoho potentsialu silskykh terytorii Ukrain [Formation and development of the economic potential of rural areas of Ukraine], Dyzain ta polihrafiia, Mykolaiv, Ukraine, $468 \mathrm{p}$.

Klub, A. I. (2013), "State regulation of socio-economic development of rural areas in Ukraine", Ph.D. Thesis, Mechanisms of Public Administration, Academy of Municipal Administration, Kyiv, Ukraine.

Lytvyn, Yu. O. (2012), "The economic situation of the modern Ukrainian village as the main component of its development", Ekonomika ta derzhava, no. 9, pp. 119-122.

Malik, M. Y. and Khvesyk, M. A. (2010), "Sustainable development of rural areas on the basis of rational nature management and ecologically safe agro-industrial production”, Ekonomika APK, no. 5, pp. 3-12.

Melnychuk, D. P. (2014), “The effect of "human capital": Economic and technical-technological determinants", Visnyk Zhytomyrskoho derzhavnoho tekhnolohichnoho universytetu. Seriia: Ekonomichni nauky, no. 2(68), pp. 131-141.

Melnychuk, D. P. and Shpytalenko, D. P. (2016), “Demographic development of the Ukrainian countryside: History lessons, socio-economic threats of the present", Visnyk Zhytomyrskoho derzhavnoho tekhnolohichnoho universytetu. Seriia: Ekonomichni nauky, no. 2, pp. 57-64.

Melnyk, L. Yu. (2007), "Status and prospects of development of the agricultural sector of the Ukrainian economy”, Derzhava ta rehiony. Seriia: Ekonomika ta pidpryiemnytstvo, no. 1, pp. 218-224.

Movchaniuk, A. V. and Diachenko, M. I. (2018), "Development of rural areas of Uman district in the conditions of decentralization", Derzhavne upravlinnia: udoskonalennia ta rozvytok, [Online], no. 1, available at: http://www.dy.nayka.com.ua/pdf/1 2018/32.pdf (Accessed 4 June 2020)

Nelep, V. M. (2014), "Ways to overcome the socio-demographic crisis in rural areas”, Ekonomika APK, no. 11, p. 56.

Neshchadym, L. M. (2011), "Cluster model of rural tourism: World experience and possibilities of its use in Ukraine”, Materialy Vseukrainskoi naukovoi konferentsii molodykh uchenykh [Proceedings of the AllUkrainian scientific conference of young scientists], Uman, Ukraine, pp. 158-159.

Padalka, S. S. (2016), “Ukrainian village in terms of socio-economic transit: transformation or survival?”, Ukrainskyi istorychnyi zhurnal, [Online], no. 4, p.108, available at: http://resource.history.org.ua/publ/UIJ 201649 (Accessed 4 May 2020)

Pavlov O. (2006), "Paradyhma silskoho rozvytku”, Ekonomika Ukrainy, no. 7, pp. 41-48.

Pavlov, O. I. (2014), Silski terytorii Ukrainy [Rural areas of Ukraine], Astra, Odesa, Ukraine, 367 p.

Prodius, O. I. (2009), "Problems of socio-economic development of rural settlements and ways to solve them", Ekonomichnyi visnyk Donbasu, no. 4(18), pp. 76-79.

Pyrozhkov, S. I. (2008), Demohrafichnyi i trudovyi potentsial [Demographic and labor potential], KNTEU, Kyiv, Ukraine, $934 \mathrm{p}$.

Riabokon, V. P. (2015), "Trends in the development of the social sphere of the village at the present stage", Ekonomika APK, no. 4, pp. 57-63. 
Sabluk, P. T. (ed.) and Yakuba, K. I. (2002), “Demographic problems of the Ukrainian village”, IAE UAAN, Kyiv, Ukraine, 38 p.

Shylepnytskyi, P. and Povoroznyk, V. (2015), "Where to find money for rural communities: Prospects and opportunities for funding from international donors", Kyiv, Ukraine, $52 \mathrm{p}$.

State Statistics Service of Ukraine (2020), Number of existing population of Ukraine as of January 1, 2020, State Statistics Service of Ukraine, Kyiv, Ukraine, $82 \mathrm{p}$. available at: http://database.ukrcensus.gov.ua/PXWEB2007/ukr/publ new1/2020/zb chuselnist\%202019.pdf (Accessed 4 May 2020)

Steshenko, V. S. (2013), “The meaning of the concepts "demographic development" and "human development": Identities and differences”, Demohrafiia ta sotsialna ekonomika, no. 1(19), pp. 5-16.

Tranchenko, L. V. (2012) "Analysis and problems of socio-economic development of the village”, Investytsii: praktyka ta dosvid, no. 5, pp. 66-69.

Yakuba, K. I. (2011), “Oznaky tryvalosti zhyttia ukrainskoho selianstva”, Visnyk ahrarnoi nauky, no. 2, pp. 6065.

Yakuba, K. I. and Sabluk, P. T. (ed.) (2011), "Socio-demographic condition of rural settlements. Organizational and economic modernization of the agricultural sector", NNTS IAE, Kyiv, Ukraine, pp. 33-40.

Zaiats, T. A. (ed.) (2017), Transformatsiia silskoho rozselennia v Ukraini [Transformation of rural settlement in Ukraine], Instytut demohrafii ta sotsialnykh doslidzhen im. M. V. Ptukhy NAN Ukrainy, Kyiv, Ukraine, 298 p.

Цей твір ліцензовано на умовах Ліцензії Creative Commons «/з Зазначенням Авторства - Некомерційна 4.0 Міжнародна» (CC BY-NC 4.0).

This is an open access journal and all published articles are licensed under a Creative Commons "Attribution-NonCommercial 4.0 International" (CC BY-NC 4.0). 